\title{
Tick Borne Virus
}

\section{Dr. Loveson Lakhani ${ }^{1 *}$ and B Mathan ${ }^{2}$}

${ }^{1}$ Department of Veterinary Surgery and Obstetrics, Sindh Agriculture University, Tandojam, Pakistan

${ }^{2}$ College of Animal Science and Technology, Yangzhou University, China

*Corresponding Author: Dr. Loveson Lakhani, Department of Veterinary Surgery and Obstetrics, Sindh Agriculture University, Tandojam, Pakistan
Received: May 15, 2021

Published: June 23, 2021

(C) All rights are reserved by Dr. Loveson

Lakhani and B Mathan.
A malady referred to as Severe Fever with blood disease Syndrome (SFTS), caused by a tick-borne virus, has killed seven and infected a minimum of sixty, setting off alarm bells among health officers in China.

Covid-19 pandemic scenario across the globe destroying the health and economy, corona virus that has infected a lot of the eighteen million folks round the world and killed over than 600 thousand folks among seven months, China is that the $1^{\text {st }}$ country wherever $1^{\text {st }}$ case was rumoured and still facing the deadly health crisis however currently different virus detected by Chinese somebody that's referred to as tick borne virus.

Severe Fever with \{thrombocytopenia| thrombopenia| blood malady| blood disorder\} Syndrome (SFTS) could be a disease, caused by a tick-borne virus. This virus killed seven folks and infected over fifty and that's triggering the alarm scenario in China.

East China's Jiangsu and Anhui provinces, the native media rumoured giant numbers of cases. over thirty folks were diagnosed with tick borne virus in Jiangsu within the months of 2020, a lot of thirty were found to be infected in Anhui.

this malady is transferred to humans through tick bites, Chinese somebody have warned that human-to-human transmission of the virus isn't potential.

\section{What is the SFTS virus?}

Severe fever with blood disease syndrome virus (SFTSV) is joined to the animal virus family and this virus is transmitted or jailbreak to humans through tick bites. The virus $1^{\text {st }}$ time known by
Chinese's researchers over years. In 2009 the primary tiny quantities of cases were rumoured in areas of Hubei and Henan provinces.

Scientist known the virus by examining the samples obtained from a bunch of individuals United Nations agency bears the similar symptoms. This virus killed over two hundredth of these infected patients. or so half-hour fatality rate is gift per CISDP.

Due to high mortality and spreadness of this virus, SFTS has been marked it among the highest fifteen priority diseases blue print by the globe Health Organization (WHO).

Scientist were certain the first vector is Associate in Nursing Asian tick referred to as Haem physalis that is carrier, of the virus. In between march and Gregorian calendar month the malady spread out and infected many folks.

April and Gregorian calendar month august the infection rate was high and somebody thought why this happens in these months. is this attributable to temperature or the supply of vector that is tick.

Farmers, hunters and pet house owners square measure special targets to the malady as they continuously are available in contact with animals that will or might not carry the Haemaphysalis longicornis tick. The virus transmitted to humans by ticks and ticks square measure gift on the body of animals like goat, sheep, bovine etc they're the most reason for spreading this malady.

Animal not show the symptoms that is joined with SFTSV and infected by this virus. The scientists opine that this malady transmits from human to human through blood and secretion. 
The Bunyaviridae family is split into arthropod-borne viruses (insects) and rodent-borne viruses (rat or mice). In livestock and humans Bunyaviruses cause several diseases as well as high fever, viral haemorrhagic fever, kidney disease, meningitis, blindness, and noninheritable issues within the livestock.

After the infection patient can show the sign and symptoms of this malady like low platelets count and free phagocyte declination within the blood. additionally there square measure some a lot of symptoms like muscle pain, severe headache, fatigue of muscles and severe coughing.

We can save United States of America by reducing the contamination that is caused by ticks. we must always destroy the ticks through spraying the liquid chemicals and therefore the powder forms on the grounds. additionally we must always care our animals from ticks.

If there's any animal that is enclosed by ticks we must always clear all the areas and acquire rid [1].

\section{Bibliography}

1. https://indianexpress.com/article/explained/tick-borne-virus-spreading-in-china-6543182/

\section{Volume 3 Issue 8 August 2021}

\section{(C) All rights are reserved by Dr. Loveson Lakhani and}

\section{B Mathan.}

